\title{
Strategy Implementation and Performance of Non Governmental Organizations in Kericho County, Kenya
}

\author{
Kipkorir Sitienei Chris Simon ${ }^{1} \&$ Daniel Kipkorir Ronoh ${ }^{2}$ \\ ${ }^{1}$ Kenyatta University, Nairobi City, Kericho campus, 1423 Kericho, 20200, Kenya \\ ${ }^{2}$ Kericho Youth Centre, Kericho County, 1346 Kericho, 20200, Kenya \\ *Correspondence: Kenyatta University, Nairobi City, Kericho campus, 1423 Kericho, 20200, Kenya. Tel: \\ 254-738-564-298 E-mail: kipkorircss@gmail.com
}

Received: June 1, 2017

doi:10.5430/mos.v4n3p34
Accepted: July 4, 2017 Online Published: July 27, 2017

URL: https://doi.org/10.5430/mos.v4n3p34

\begin{abstract}
Non-Governmental Organizations face problems related to planning, staffing, organizational change, influence of leadership on allocation of resource and competition. The study focused on strategy implementation and performance. The objectives were; to investigate the effect of resource allocation, role of staff involvement, influence of reward systems, effect of operating procedures and role of communication on performance. The study is important to Non-Governmental Organizations, board of directors, donors and government. The study used McKinsey 7s model, survey research design. The target population was 37 the organizations and 349 members of the management team. Stratified technique was used to categorize the management into Board of Governors, managing directors, managers and heads of departments/project officers. A sample size of 151 respondents was selected from the categories. Data was collected and analyzed using descriptive and inferential statistics with the aid of Statistical Package for Social Sciences (SPSS) version 21. The analyzed data was presented in form of frequency distribution tables. The findings indicated that Strategy operationalization through resource allocation (allocation of money, adequate personnel and staff involvement to implement new strategies) and operating procedures (staff training, policies, guiding principles to ensure compliance to organization's strategy, procedures, capacity of management, strategic guidance of top management) affect performance to varying levels, Strategy institutionalization, through communication and reward system (clear goals and objectives, strategy direction, strategy clearly communicated, performance recognition system, effort based rewards and rewards system linked to new strategy affect performance differently.
\end{abstract}

Keywords: strategy implementation; performance of non governmental organizations; Kericho county; Kenya

\section{Introduction}

Non Governmental Organizations face internal management problems in planning, staffing, leadership and governance, strategy implementation and limited resources. Their performance is affected by political instability, government policies, overdependence on donor partners (Dimelu, Salua and Igbokwe, 2013). Strategy implementation is difficult for many organizations. Non Governmental Organizations in Kericho county and Kenya have constantly have problems governance, technical capacity, and resource mobilization thus failing to implement interventions that are sustainable. According to Youth Centre annual report of 2013 perennial problems negatively influence their effort to achieve goals. Researches in strategy implementation has focused mostly on formulation and implementation in the private sector and rare in Non Governmental Organizations as argued by Stone Bigelow and Crittenden (1999). Several studies have been carried out in profit oriented institutions (Amah and Ahiauzu, 2013). Many studies have focused on leadership, structure and culture as broad areas in strategy implementation (Mbaka and Mugambi 2014; Rajasekar, 2014). The study investigated the effect of strategy implementation especially in operationalization and institutionalization of strategies on performance

\section{Objectives}

1. To investigate effect of resource allocation on organizational performance of Non Governmental Organizations 
2. To determine the role of staff involvement on organizational performance of Non Governmental Organizations)

3. To determine influence of reward systems on organizational performance of Non -Governmental Organizations

4. To examine effect of operating procedures on organizational performance of Non Governmental Organizations

5. To establish role of communication on organizational performance of Non Governmental Organizations

\section{Hypotheses}

$\mathrm{Ho}_{\mathrm{i}}$ : There is no significant effect of operationalization of strategies on organizational performance

Ho ii: There is no significant effect of institutiolization of strategies on organizational performance

\section{Literature Review}

Strategic planning and strategy implementation form strategic management process (Ansoff, 1987; Hofer and Schendel, 1980; Nutt, 1989 cited in Sharp and Brock, 2012). They argue that the later involves the execution of strategies. It is the total sum of actions requiring resources to fulfill the objectives (1986). The result will be new structures, processes and alignment of the organization (Galbraith and Kazanjian, 1986). Many organizations have failed to actualize the implementation for accomplishment of organizations' goals (Shah, 1996). Davis (1996) links companies objectives to organizational performance. He argues that the managers focus on financial objectives while employees on objectives related to production quality, volume and service. Without a clear attention on the two levels of objectives it is difficult to establish how they are connected. It is possible to achieve objectives by converting strategic plans into actions (Steiss 2003). Translate strategies into actions for successful attainment of organizations' vision, mission and objectives (Hill and Jones, 2011. Implementation can be further achieved through development of procedures, programs and budgets (Wheelen and Hunger, 2011). Therefore implementation involves putting into actions the strategies that have been established in order to achieve an organization's objectives and mission.

Strategic management in organizations is justified based on performance in terms profits and return on investment (Thomas, Wheelen \& Hunger, 2012). The increase in performance and competitive advantage depend on a set of consistent strategies developed and put to action (Hill, Jones \& Schilling (2014). A review of empirical literature on strategic leadership and organizational performance has focused majorly on finance (Carter and Greer, 2013). Academic literature focuses on organizational performance whose aspects vary from one institution to another in context and time period. In the nineteen fifties its evaluation was based on work, organizational structure, people and a social system directed towards achieving goals and objectives (Georgopoulos and Tannenbaum, 1957). In the sixties and seventies, it was well-defined as an organization's capacity and ability to exploit its surrounding (environment) using the scarce resources to maximize profits (Yuchtman and Seashore, 1967). The concept is a collection of nonfinancial and financial variables which provide information on the level of attainment of results and set objectives (Kaplan and Norton, 1992). In the eighties and nineties the focus of organizational performance was on efficiency and effectiveness. Managers began realizing that organizations were successful if they achieved their goals and objectives using minimum available resources (Lusthaus and Adrien, 1998). Non Governmental Organizations are not profit oriented and therefore focus on meeting social needs hence their performance indicators are mostly non-financial. Studies show that most of them have inadequate financial, capital, technical resources, and managerial skills to address problems. To adapt to the changes in the environment the organizations are implementing plans (Ramadan, 2015).

Dooley, Fryxell and Judge (2000) employed hierarchical regression in their study to determine the group of relationships linked to consensus of strategic direction in hospital in South-eastern, United States. Decision consensus was key in building decision commitment, which eventually affects the success of implementation. Omboi (2011)) carried out a study in Meru Kenya and the findings indicated that policies, behaviour of the managerial team, resource allocation, and leadership influenced implementation of strategies. Research by Okorley and Nkrumah (2012) showed that availability of funds, supportive leadership, development of demand-driven and needs-based programmes and effective management have effects on sustainability of local Non Governmental Organizations. Leadership was the most critical factor while quality and ease of access to material resources for work were least 
important but significant in contributing to sustainability. A study done by Enz (2012) in America found out that some strategies, individual's involvement and participation, use of rewards, bench marking, focus groups, and senior management review process were strongly correlated to innovation success. Further findings pointed out the participative strategies were highly correlated to innovation success. Amah and Ahiauzu's (2013) study established that training and staff involvement in decision making improve their productivity hence achievement of organizational goals, increase in profitability and market share.

Obadha-Mwawasi, Wanjau, and Mkala (2013) examined factors which affect implementation of operational strategies in Non Governmental Organizations in Kenya. Placement of operational strategies and availability of resource greatly improve implementation was the outcome. Information technology was key in regard to the execution of the strategies. There is need for employees and management with the right skills, effective strategies and competence to facilitate strategy implementation. Brinkschröder's (2014) research in the Netherlands revealed that support and motivation develop organizational culture which enhances working atmosphere and facilitates effective implementation. Patel, Booker, Ramos and Bart, (2015) found out that mission statements had a significant positive relationship with organizational performance with commitment being a moderator variable. Higher levels of commitment increased the effect of the mission on performance. Sang, Kindiki, Rotich and Kipruto (2015) did a research and found out that (8) $9.4 \%$ ) of the secondary schools have functional strategic plans while the majority (77) 90.6\%) had none for achievement of goals, mission and vision. However, (81.82\%) of the principals were yet to develop one. Opano, Shisia, Sang and Josee (2013 as cited in Gaogallo, 2015) investigated on strategic planning and implementation practices at the Kisii county government in Kenya. Human and financial resources were mainly needed in the implementation of the strategic plans. The study revealed that the county was constrained financially and it is a big challenge to implement some of the activities outlined in their strategic plan.

\section{Theoretical Framework}

McKinsey 7s is management framework developed by Robert Waterman Jr. and Tom Peters in the 1980s. The model's structure, strategy, systems, style, staff, shared values and skills enable organizations to perform (Ravanfar, 2015). Strategy is the rational set of actions to achieve competitive advantage. Style is the behavioural patterns used by the organizational leadership. Skills include the attributes and capabilities to do work. Systems consist of the business and technical infrastructure that personnel use for their day to day accomplishment of organization goals. Structure is the formal authority and responsibility while the Staff refers to the people engaged in organizational activities. Shared values are the guiding set of traits, behaviours, and characteristics underlying the desired corporate destiny. The theory addresses the concepts of operationalization and institutionalization of strategies as indicated in the conceptual framework of the study.

According to Mugenda and Mugenda (2003) conceptual framework refers to when a researcher conceptualizes the relationship between variables in the study and shows the relationship between them graphically or diagrammatically. The aim of a conceptual model is to help the reader to quickly see the proposed relationships.

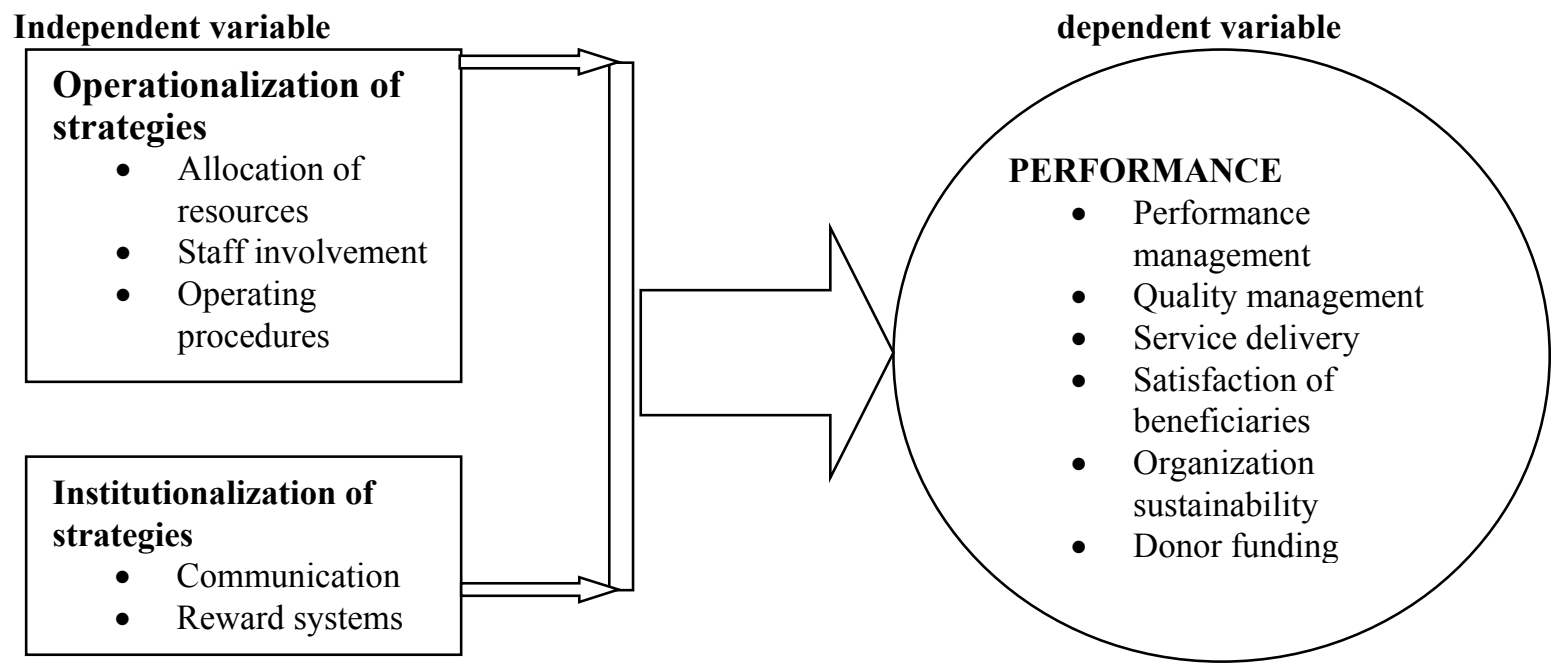

Figure 1. Conceptual Framework of the Study (Source: Authors (2016)) 
Strategy implementation constitutes the independent variable while organizational performance is the dependent variable. Strategy implementation comprises operationalization and institutionalization of strategies. Performance consist of Performance management, quality management, Service delivery, Satisfaction of beneficiaries, organization sustainability, and donor funding

\section{Methodology}

Survey research design, stratified and simple random sampling techniques were were used. Random sampling was considered to be appropriate as argued by (Marczyk, DeMatteo and Festinger, 2005). Simple random sampling is the sampling process that ensures each element in the population will have an equivalent chance of being incorporated in the sample (Zikmund, Babin, Carr and Griffin, 2013). According to Kothari (2004) a stratified random sample is used when the population is not homogeneous. The sample consisted of two or more subgroups. Data was analyzed using inferential statistics with the aid of Statistical Package for Social Sciences (SPSS) software version 21. The analyzed data was presented using frequency distribution tables. Multiple regression model used is indicated below:

$\mathrm{Y}=1.876+0.227 \mathrm{X} 1+0.325 \mathrm{X} 2+\varepsilon$

Where $\mathrm{Y}=$ Dependent variable (organizational performance)

$\beta 0=$ constant term

$\beta=$ the parameter coefficient which is linear and determines the power of the model

$\mathrm{X} 1=$ operationalization of strategy

$\mathrm{X} 2=$ institutionalization of strategy

$\varepsilon=$ standard error term

\section{Results and Discussion}

Form a target of 151 questionnaires distributed to the respondents, the return rate was 138 representing $91.391 \%$ hence excellent. Response rate of $50 \%$ is adequate for analysis and reporting while $60 \%$ is good and $70 \%$ and over is excellent (Mugenda and Mugenda, 1999).

The reliability of the research instrument was determined using the Cronbach's alpha coefficient. The reliability according to Cronbach's alpha coefficient equal or above 0.70 can be considered satisfactory hence the adoption of the research instrument as reliable for the study

Cronbach's formula

$$
\alpha=\frac{\mathbf{n}}{\mathbf{n}-1}\left(1-\frac{\sum_{\mathrm{i}} \mathrm{V}_{\mathrm{i}}}{\mathrm{V}_{\mathrm{t}}}\right)
$$

$\mathrm{n}$ is the number of items, $\mathrm{V}$ i is the variance of the total scores and $\mathrm{Vt}$ is the variance of the item scores.

Therefore; $\alpha=20 / 20-1(1-54.3751 / 490.75)$

$=0.936$. The alpha result of 0.936 is greater than 0.70 hence the research instrument was reliable.

\section{Operationalization of Strategies}

Table 1 shows that $55(35 \%)$ strongly agreed that money was allocated to implement new strategies by Non Governmental Organizations, 67 (42.7\%) agreed. One (0.6\%) did not respond. The respondents who strongly agreed that their organization had adequate personnel assigned to implement new strategies were $78(49.7 \%), 42(26.8 \%)$ agreed, $3(1.9 \%)$ did not participate; $71(45.2 \%)$ strongly agreed, $62(39.5 \%)$ agreed, that staff members are involved and $2(1.3 \%)$ didn't provide feedback 
Table 1. Resource Allocation

\begin{tabular}{lllllll}
\hline & SA & A & N & D & SD & MISSING \\
\hline Money is allocated to implement new & 55 & 67 & 5 & 21 & 8 & 1 \\
strategies & $(35 \%)$ & $(42.7 \%)$ & $(3.2 \%)$ & $(13.4 \%)$ & $(5.1 \%)$ & $(0.6 \%)$ \\
organization has adequate personnel & 78 & 42 & 8 & 15 & 11 & 3 \\
assigned to implement new strategies & $(49.7 \%)$ & $(26.8 \%)$ & $(5.1 \%)$ & $(9.6 \%)$ & $(7 \%)$ & $(1.9 \%)$ \\
Staff involvement is practiced & 71 & 62 & 54 & 7 & 1 & 2 \\
& $(45.2 \%))$ & $(39.5 \%)$ & $(8.9 \%)$ & $(4.5 \%)$ & $(0.6 \%)$ & $(1.3 \%)$ \\
\hline
\end{tabular}

Source: Research data (2016)

Table 2. Operating Procedures

\begin{tabular}{|c|c|c|c|c|c|c|}
\hline & SA & $\mathrm{A}$ & $\mathrm{N}$ & $\mathrm{D}$ & $\mathrm{SD}$ & MISSING \\
\hline $\begin{array}{l}\text { staff training on the new } \\
\text { strategies is done }\end{array}$ & $\begin{array}{l}96 \\
(61.1 \%))\end{array}$ & $\begin{array}{l}36 \\
(22.9 \%)\end{array}$ & $\begin{array}{l}15 \\
(9.6 \%)\end{array}$ & $\begin{array}{l}3 \\
(1.9 \%)\end{array}$ & $\begin{array}{l}3 \\
(1.9 \%)\end{array}$ & - \\
\hline $\begin{array}{l}\text { Organizational policies have } \\
\text { been revised to suit the new } \\
\text { strategies }\end{array}$ & $\begin{array}{l}64 \\
(40.8 \%)\end{array}$ & $\begin{array}{l}33 \\
(21 \%)\end{array}$ & $\begin{array}{l}44 \\
(26.1 \%)\end{array}$ & $\begin{array}{l}16 \\
(10.2 \%)\end{array}$ & $\begin{array}{l}3 \\
(1.9 \%)\end{array}$ & - \\
\hline $\begin{array}{l}\text { Policies guide managerial } \\
\text { actions to ensure compliance } \\
\text { with the organization's strategy. }\end{array}$ & $\begin{array}{l}43 \\
(27.4 \%)\end{array}$ & $\begin{array}{l}78 \\
(49.7 \%)\end{array}$ & $\begin{array}{l}17 \\
(10.8 \%)\end{array}$ & $\begin{array}{l}7 \\
(4.5 \%)\end{array}$ & $\begin{array}{l}12 \\
(7.6 \%)\end{array}$ & - \\
\hline $\begin{array}{l}\text { The organization's procedures } \\
\text { define how the it intends to } \\
\text { operate in future }\end{array}$ & $\begin{array}{l}77 \\
(49.8 \%)\end{array}$ & $\begin{array}{l}57 \\
(36.3 \%)\end{array}$ & $\begin{array}{l}17 \\
(10.8 \%)\end{array}$ & $\begin{array}{l}4 \\
(2.5 \%)\end{array}$ & $\begin{array}{l}2 \\
(1.3 \%)\end{array}$ & - \\
\hline $\begin{array}{l}\text { Changes by leadership is } \\
\text { effected to suit a new or revised } \\
\text { strategy }\end{array}$ & $\begin{array}{l}22 \\
(14.0 \%)\end{array}$ & $\begin{array}{l}41 \\
(26.1 \%)\end{array}$ & $\begin{array}{l}26 \\
(16.6 \%\end{array}$ & $\begin{array}{l}46 \\
(29.3 \%)\end{array}$ & $\begin{array}{l}17 \\
(10.8 \%)\end{array}$ & $\begin{array}{l}5 \\
(3.2 \%)\end{array}$ \\
\hline $\begin{array}{l}\text { The organization has a } \\
\text { management capacity to oversee } \\
\text { funding }\end{array}$ & $\begin{array}{l}56 \\
(35.7 \%)\end{array}$ & $\begin{array}{l}57 \\
(36.3 \%)\end{array}$ & $\begin{array}{l}20 \\
(12.7 \%)\end{array}$ & $\begin{array}{l}19 \\
(12.1 \%)\end{array}$ & - & $\begin{array}{l}5 \\
(3.2 \%)\end{array}$ \\
\hline $\begin{array}{l}\text { Executive director and } \\
\text { management team provide } \\
\text { strategic guidance to the staff }\end{array}$ & $\begin{array}{l}60 \\
(38.2 \%)\end{array}$ & $\begin{array}{l}64 \\
(40.8 \%)\end{array}$ & $\begin{array}{l}24 \\
(15.3 \%)\end{array}$ & $\begin{array}{l}6 \\
(3.8 \%)\end{array}$ & - & $\begin{array}{l}3 \\
(1.9 \%)\end{array}$ \\
\hline
\end{tabular}

Source: Research data (2016)

Table 2 shows that, $96(61.1 \%)$ strongly agreed, $36(22.9 \%)$ agreed that staff members are trained on the new strategies, $64(40.8 \%)$ strongly agreed, 33 (21\%) agreed, $44(26.1 \%)$ were neutral that organizational policies have been revised to suit the new strategies. Forty three $(27.4 \%)$ strongly agreed that policies guided managerial actions to ensure compliance with the organization's strategy, 78 (49.7\%) agreed, $17(10.8 \%)$ were neutral. Respondents who strongly agreed that the organization's procedures define how the organization intended to operate in the future were $77(49.0 \%), 57(36.3 \%)$ agreed, $17(10.8 \%)$ were neutral. Twenty two (14.0\%) strongly agreed that leadership changes are effected to suit a new or revised strategy, $41(26.1 \%)$ agreed, 26 (16.6\%) were neutral, 46 (29.3\%) disagreed, 17 (10.8\%) strongly disagreed but 5(3.2\%) didn't respond

Concerning organization having a management capacity to oversee funding, 56 (35.7\%) strongly agreed, 57 (36.3\%) agreed, $20(12.7 \%)$ were neutral, $19(12.1 \%)$ disagreed but $5(3.2 \%)$ were non committal. Sixty (38.2\%) were strongly in agreement that executive director and management team provide strategic guidance to the organization's staff, 64 (40.8\%) agreed, 24 (15.3\%) were neutral but 3 (1.9\%) did not indicate their level of agreement. 
Table 3. Institutionalization of Strategies

\begin{tabular}{lllllll}
\hline Communication and reward system & $\mathrm{SA}$ & $\mathrm{A}$ & $\mathrm{N}$ & $\mathrm{D}$ & $\mathrm{SD}$ & MISSING \\
\hline The organization's goals and & 66 & 59 & 3 & 3 & 6 & - \\
objectives are clear to all employees. & $(54.8 \%)$ & $(37.6 \%)$ & $(1.9 \%)$ & $(1.9 \%)$ & $(3.8 \%)$ & \\
Strategy direction is clear to all & 59 & 75 & 12 & 4 & 2 & 5 \\
employees. & $(54.8 \%)$ & $(47.8 \%)$ & $7.6 \%)$ & $(2.5 \%)$ & $(1.3 \%)$ & $(3.2 \%)$ \\
New strategies are clearly & 69 & 57 & 11 & 2 & 5 & 13 \\
communicated to staff & $(43.9 \%)$ & $(36.3 \%)$ & $(7.0 \%)$ & $(1.3 \%)$ & $(3.2 \%)$ & $(8.3 \%)$ \\
organization has instituted a & 22 & 49 & 26 & 35 & 19 & 6 \\
performance recognition system & $(14.0 \%)$ & $(31.2 \%)$ & $(16.6 \%)$ & $(12.1 \%)$ & $(3.8 \%)$ & $(3.8 \%)$ \\
Individuals are rewarded for their & 13 & 26 & 32 & 42 & 40 & 5 \\
efforts & $(8.3 \%)$ & $(16.6 \%)$ & $20.4 \%)$ & $(26.1 \%)$ & $(25.5 \%)$ & $(3.2 \%)$ \\
Reward system is linked to the new & 5 & 16 & 325 & 46 & 48 & 7 \\
strategies & $(8.3 \%)$ & $(10.2 \%)$ & $(22.3 \%)$ & $(29.3 \%)$ & $(30.6 \%)$ & $(4.5 \%)$ \\
\hline
\end{tabular}

Source: Research data (2016)

On clarity of the organization's goals and objectives to all employees, $86(54.8 \%)$ strongly agreed, 59 (37.6\%) agreed but 5 (3.2\%) didn't provide any information. On strategy direction being clear to all employees, 59 (37.6\%) respondents strongly agreed, $75(47.8)$ agreed, $12(7.6 \%)$ were neutral. Regarding new strategies being clearly communicated to staff, 69 (43.9\%) strongly agreed, 57 (36.3\%) agreed, $11(7.0 \%)$ were neutral, however $13(8.3 \%)$ didn't participate. Twenty two (14.0\%) strongly agreed that the NGOs, have instituted a performance recognition system, 49 (31.2\%) agreed, $26(16.6 \%)$ were neutral, 35 (22.3\%) disagreed, $19(12.1 \%)$ strongly disagreed but 6 (3.8\%) didn't respond. Thirteen (8.3\%) strongly agreed that individuals are rewarded for their efforts, $26(16.6 \%)$ agreed, 32 (20.4\%) were neutral, $42(26.1 \%)$ disagreed, 40 (25.5\%) strongly disagreed while $5(3.2 \%)$ didn't provide feedback. Five (3.2\%) strongly agreed that reward system are linked to new strategies, $16(10.2 \%)$ agreed, $35(22.3 \%)$ were neutral, 46 (29.3\%) disagreed, 48 (30.6\%) strongly disagreed and 7 (4.5\%) were non participant.

Table 4. Organizational Performance

\begin{tabular}{lllllll}
\hline & $\mathrm{SA}$ & $\mathrm{A}$ & $\mathrm{N}$ & $\mathrm{D}$ & $\mathrm{SD}$ & MISSING \\
\hline Performance management enhance & 42 & 82 & 22 & 6 & 2 & 3 \\
organizational performance & $(268 \%)$ & $(52.2 \%)$ & $(14.0 \%)$ & $(3.8 \%)$ & $(1.3 \%)$ & $(1.9 \%)$ \\
Quality management improve & 40 & 87 & 22 & 16 & 4 & 2 \\
performance & $(25.5 \%)$ & $(55.4 \%)$ & $(14.0 \%)$ & $(10.2 \%)$ & $(2.5 \%)$ & $(1.3 \%)$ \\
Service delivery determine organizational & 53 & 86 & 9 & 5 & 2 & 2 \\
performance & $(36.8 \%)$ & $(54.8 \%)$ & $(5.7 \%)$ & $(3.2 \%)$ & $(1.3 \%)$ & $(1.3 \%)$ \\
Organization sustainability affect & 58 & 75 & 20 & 2 & - & 2 \\
organizational performance & $(38.8 \%$ & $(47.8 \%)$ & $(12.7 \%)$ & $(1.3 \%)$ & & $(1.3 \%)$ \\
Satisfaction by beneficiaries plays a role & 49 & 61 & 33 & 9 & 3 & 2 \\
in organizational performance & $(31.2 \%$ & $(38.9 \%)$ & $(21.0 \%)$ & $(5.7 \%)$ & $(1.9 \%)$ & $(1.3 \%)$ \\
Donor funding support organizational & 64 & 53 & 27 & 7 & 4 & 2 \\
performance & $(40.7 \%$ & $(33.8 \%)$ & $(17.2 \%)$ & $(4.5 \%)$ & $(2.5 \%)$ & $(1.3 \%)$ \\
\hline
\end{tabular}

Source: Research data (2016) 
Table 4 indicates that $42(26.8 \%)$ strongly agreed that performance management has enhanced organizational performance, $82(52.2 \%)$ agreed, $22(14.0 \%)$ were neutral. On quality management, $40(25.5 \%)$ strongly agreed that it had improved performance, $87(55.4 \%)$ agreed, $22(14.0 \%)$ were neutral. Concerning the extent to which service delivery has affected performance, 53 (38.8\%) strongly agreed, $86(54.8 \%)$ agreed. On organization sustainability with regards to performance, $58(36.9 \%)$ strongly agreed, $75(47.8 \%)$ agreed, $20(12.7 \%)$ were neutral, $2(1.3 \%)$ disagreed, $2(1.3 \%)$ nobody strongly disagreed. On satisfaction by beneficiaries and the effect it had on organizational performance, $49(31.2 \%)$ strongly agreed, $61(38.9 \%)$ agreed, $33(21.0 \%)$ were neutral. About donor funding in relation to organizational performance $64(40.8 \%)$ strongly agreed, $53(33.8 \%)$ agreed, $27(17.2 \%)$ were neutral. In all cases two (1.3\%) didn't provide feedback except $3(1.9 \%)$

Table 5. Institutionalization and Operationalization of Strategies on Organizational Performance

\begin{tabular}{lllllll}
\hline & $\mathrm{SA}$ & $\mathrm{A}$ & $\mathrm{N}$ & $\mathrm{D}$ & $\mathrm{SD}$ & MISSING \\
\hline operationalization of strategy has & 73 & 54 & 16 & 6 & 4 & 4 \\
led to sustainability & $(46.5 \%)$ & $34.2 \%)$ & $(10.2 \%)$ & $(3.8 \%)$ & $(2.5 \%)$ & $(2.5 \%)$ \\
Operationalization of strategy has & 45 & 69 & 17 & 17 & 5 & 4 \\
led to increase in donor funding & $(28.7 \%)$ & $(43.9 \%)$ & $(10.8 \%)$ & $(10.8 \%$ & $(3.2 \%)$ & $(2.5 \%)$ \\
institutionalization of strategy has & 67 & 77 & 7 & - & 2 & 4 \\
led to improved service delivery & $(42.7 \%)$ & $(49.0 \%)$ & $(4.5 \%)$ & & $(1.3 \%)$ & $(2.5 \%)$ \\
Institutionalization of strategy has & 68 & 69 & 14 & 2 & - & 4 \\
led to satisfaction by beneficiaries & $(43.3 \%)$ & $(43.9 \%)$ & $(8.9 \%)$ & $(1.3 \%)$ & & $(2.5 \%)$ \\
\hline
\end{tabular}

Source: Research data (2016)

Table 5 shows that 73 (46.5\%) strongly agreed that operationalization of strategy has led to sustainability, 54 (34.4\%) agreed, $16(10.2 \%)$ were neutral. On operationalization of strategy leading to increase in donor funding, $45(28.7 \%)$ strongly agreed, $69(43.9 \%)$ agreed, $17(10.8 \%)$ were neutral. Concerning institutionalization leading to improved service delivery, $67(42.7 \%)$ strongly agreed, 77 (49.0\%) agreed. Regarding institutionalization having led to satisfaction by beneficiaries $68(43.3 \%)$ strongly agreed, $69(43.9 \%)$ agreed. In all the cases $4(2.5 \%)$ didn't participate

Table 6. Regression Analysis (Coefficients) Institutionalization and Operationalization of Strategies on Organizational Performance Using SPSS Version 20

\begin{tabular}{|c|c|c|c|c|c|c|c|c|}
\hline \multirow[t]{2}{*}{ Model } & \multicolumn{2}{|c|}{$\begin{array}{l}\text { Unstandardized } \\
\text { Coefficients }\end{array}$} & \multirow{2}{*}{$\begin{array}{l}\text { Standardized } \\
\text { Coefficients } \\
\text { Beta }\end{array}$} & \multirow[t]{2}{*}{$\mathbf{t}$} & \multirow[t]{2}{*}{ Sig. } & \multicolumn{3}{|c|}{ Correlations } \\
\hline & B & $\begin{array}{l}\text { Std. } \\
\text { Error }\end{array}$ & & & & Zero-o & Partial & Part \\
\hline (Constant) & 2.810 & 0.299 & & 9.398 & 0.000 & & & \\
\hline $\begin{array}{l}\text { Operationalization } \\
\text { strategies }\end{array}$ & of 0.333 & 0.061 & 0.413 & 5.451 & 0.000 & 0.638 & 0.227 & 0.137 \\
\hline $\begin{array}{l}\text { Institutiolization } \\
\text { strategy }\end{array}$ & of -0.42 & 0.061 & -0.052 & -0.687 & 0.493 & 0.475 & 0.386 & 0.245 \\
\hline
\end{tabular}

Source: Research data (2016)

Using an alpha of 0.05 , the coefficient (t-statistics) on operationalization of strategies is 5.451 with p-value $(0.000)$ which is less than 0.05 . The hypothesis "there is no significant effect of operationalization strategies on performance" was rejected

The coefficient (t-statistics) on institutionalization of strategy $(-0.687)$ has $p$ value of 0.493 which is greater than 
0.05. The hypothesis "there is no significant effect of institutiolization strategies on performance" was accepted

\section{Conclusion}

Strategy implementation moderately influences organizational performance through operationalization and institutionalization strategies. It improves service delivery, sustainability, satisfaction by beneficiaries, and donor funding. The result is obligation by management to provide strategic guidance to the organization's staff, to enhance communication and allocate money to train employees on new strategies. Its success depends on different abilities, organizational processes and flexible systems for selection of strategy. Therefore leaders shape the future by enabling an organization to produce excellent performance by means of implementing an outstanding strategic plan. A well-formulated and appropriate strategy will enable an organization to improve, achieve good planning, mission, vision and overall corporate success (Crittenden and Crittenden, 2008). The view suggests that the two aspects of strategy implementation (operationalization and institutionalization) are complementary and either is ineffective in the total absence of the other. The Non Governmental Organizations should effectively implement strategies to be competitive. They perform well when strategy operationalization (allocation of resources, staff involvement and operating procedures) and strategy institutionalization (Communication and reward systems) are included in the strategic management process. The performance relies on maximization of human resources, organizational resources and physical resources.

\section{Recommendation}

Further research to be done on strategic planning and the performance of other organizations.

\section{Acknowledgements}

The article writing has been possible due to support from several people whom Library assistants of Kenyatta university and reviewers of the article

\section{References}

Amah, E., \& Ahiauzu, A. (2013). Employee involvement and organizational effectiveness. Journal of Management Development, 32(7), 661-674. https://doi.org/10.1108/JMD-09-2010-0064

Brinkschröder, N. (2014). Strategy implementation: Key factors, challenges and solutions (Bachelor's thesis, University of Twente).

Carter, S. M., \& Greer, C. R. (2013). Strategic leadership: Values, styles, and organizational performance. Journal of Leadership \& Organizational Studies, 20(4), 375-393. https://doi.org/10.1177/1548051812471724

Davis, T. R. (1996). Developing an employee balanced scorecard: linking frontline performance to corporate objectives. Management Decision, 34(4), 14-18. https://doi.org/10.1108/00251749610115116

Dimelu, M. U., Salua, E. S., \& Igbokwe, E. M. (2013). Performance of faith-based grassroot non-governmental organisations in rural development in Nasarawa State, Nigeria. International NGO journal, 8(7), 146-152. https://doi.org/10.5897/INGOJ2013.0276B

Dooley, R. S., Fryxell, G. E., \& Judge, W. Q. (2000). Belaboring the not-so-obvious: Consensus, commitment, and strategy implementation speed and success. Journal of management, 26(6), 1237-1257. https://doi.org/10.1177/014920630002600609

Enz, C. A. (2012). Strategies for the implementation of service innovations. Cornell Hospitality Quarterly, 53(3), 187-195. https://doi.org/10.1177/1938965512448176

Galbraith, J. R. (1986). Strategy implementation; structure, systems and process (No. 04; HD31, G3 1986.).

Galgallo, A. W. (2015). Strategy Implementation Challenges in the Devolved Government Units: Case of Mombasa County, Kenya (Doctoral dissertation, University of Nairobi).

Georgopoulos, B. S., \& Tannenbaum, A. S. (1957). A study of organizational effectiveness. American Sociological Review, 22(5), 534-540. https://doi.org/10.2307/2089477

Hill, C., \& Jones, G. (2011). Essentials of strategic management. Nelson Education. 
Kaplan, R. S., \& Norton, D. P. (1996). Using the balanced scorecard as a strategic management system. Harvard Business Review, 74(1), 75-85

Kothari, C. R. (2004). Research methodology: Methods and techniques. New Age International.

Lusthaus, C., \& Adrien, M. H. (1998). Organizational assessment: A review of experience. Universalia Occasional Paper, 31 .

Marczyk, G., DeMatteo, D., \& Festinger, D. (2005). Essentials of research design and methodology. John Wiley \& Sons Inc.

Mbaka, R. M., \& Mugambi, F. (2014). Factors affecting successful strategy implementation in the Water Sector in Kenya. IOSR Journal of Business and Management, 16(7), 61-68. https://doi.org/10.9790/487X-16736168

Mugenda, O. M., \& Mugenda, A. G. (1999). Research Methods: Quantitative and Qualitative Strategies. Acts Press, Nairobi.

Mugenda, O. M., \& Mugenda, A. G. (2003). Quantitative and qualitative research methods. Nairobi: African Centre for Technology Studies.

Obadha-Mwawasi, T., Wanjau, K., \& Mkala, M. (2013). Factors affecting implementation of operational strategies in Non-Governmental Organizations in Kenya. Global Journal of Human Resource Management, 1(4), 10-19.

Okorley, E. L., \& Nkrumah, E. E. (2012). Organisational factors influencing sustainability of local non-governmental organisations: Lessons from a Ghanaian context. International Journal of Social Economics, 39(5), 330-341. https://doi.org/10.1108/03068291211214190

Omboi, B. M. (2011). Factors affecting the implementation of strategic plans in government tertiary institutions: A survey of selected technical training institutes. European Journal of Business and Management, 3(3), 85-105.

Patel, B. S., Booker, L. D., Ramos, H. M., \& Bart, C. (2015). Mission statements and performance in non-profit organisations. Corporate Governance, 15(5), 759-774. https://doi.org/10.1108/CG-07-2015-0098

Rajasekar, J. (2014). Factors affecting effective strategy implementation in a service industry: A study of electricity distribution companies in the Sultanate of Oman. International Journal of Business and Social Science, 5(9), 169-183.

Ramadan, M. A. (2015). The Impact of Strategy Implementation Drivers on Projects Effectiveness in Non-Governmental Organizations. International Journal of Academic Research in Management, 4(2), 35-47.

Ravanfar, M. M. (2015). Analyzing Organizational Structure based on 7s Model of McKinsey. International Journal of Academic Research in Business and Social Sciences, 5(5), 43-55. https://doi.org/10.6007/IJARBSS/v5-i5/1591

Sang, F. K., Kindiki, J. N., Sang, J. K., Rotich, G. J., \& Kipruto, K. (2015). Availability and the Level of Implementation of Strategic Plans in Secondary Schools in Nandi County, Kenya. SAGE Open, 5(2), 2158244015577417. https://doi.org/10.1177/2158244015577417

Shah, A. M. (1996). Strategy implementation: A study of critical factors. Indian journal of industrial relations, 42-55.

Sharp, Z., \& Brock, D. M. (2012). Implementation through risk mitigation: Strategic processes in the nonprofit organization. Administration \& Society, 44(5), 571-594. https://doi.org/10.1177/0095399711418325

Steiss, A. W. (Ed.). (2003). Strategic management for public and nonprofit organizations. CRC Press.

Stone, M. M., Bigelow, B., and Crittenden, W. (1999). Research on strategic management in non-profit organizations: Synthesis, analysis and future directions. Administration and Society, 31, 378-423. https://doi.org/10.1177/00953999922019184

Thomas L. Wheelen \& Hunger, J. D. (2012). Strategic management and business policy: toward global sustainability. Pearson/Prentice Hall.

Wheelen, T. L., \& Hunger, J. D. (2011). Concepts in strategic management and business policy (13th ed.) Upper Saddle River, NJ: Pearson Prentice Hall.

Yuchtman, E., \& Seashore, S. E. (1967). A system resource approach to organizational effectiveness. American sociological review, 32(6), 891-903. https://doi.org/10.2307/2092843

Zikmund, William G., Barry J. Babin, Jon C. Carr \& Mitch Griffin. (2013). Business research methods. Cengage Learning. 